\title{
Zoogeography of marine parasites
}

\author{
K. Rohde \\ Department of Zoology, University of New England; Armidale, N.S.W., 2351, Australia
}

\begin{abstract}
Latitudinal gradients in species numbers of marine parasites, differences between the Atlantic and Indo-Pacific Oceans, latitudinal gradients in frequency and intensity of infection, in host range and specificity, and in fluctuations of infection are discussed, as well as differences between shallow and deep water, parasite endemicity at remote oceanic islands, and importance of temperature for parasite distribution. Examples are given to demonstrate the usefulness of marine parasites as biological tags and as indicators of the geographical origin of hosts.
\end{abstract}

\section{INTRODUCTION}

The study of the geographical distribution of marine parasites is in its infancy. Comprehensive treatises on marine zoogeography ignore parasites completely (Ortmann, 1896; Ekman, 1935, 1953; Briggs, 1974), comparable to the neglect of parasites in early books on general zoogeography (e.g. Schmarda, 1853; Hesse, 1924; Hesse et al.,

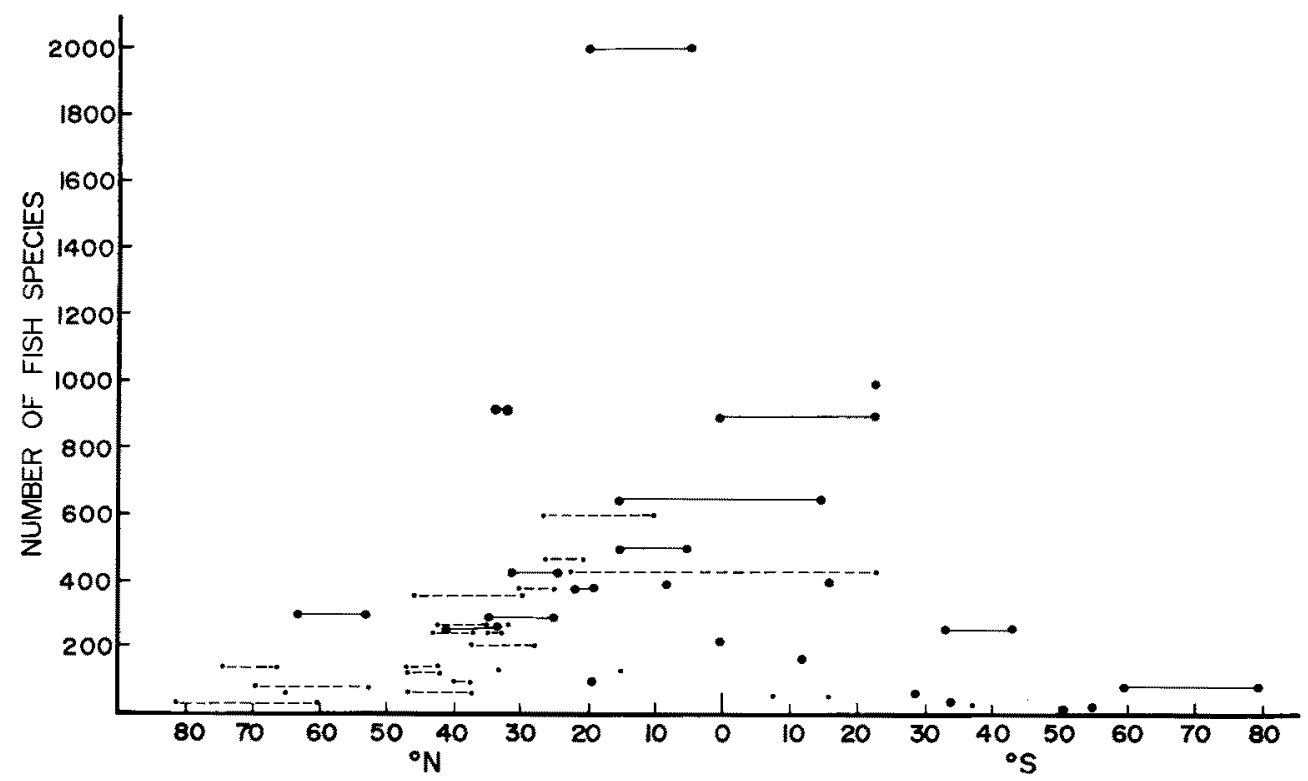

Fig. 1. Numbers of marine fish species at different latitudes. Small dots, interrupted line: Atlantic. Large dots, uninterrupted line: Indo-Pacific. Ordinate: number of fish species. Abscissa: latitude.

(Redrawn after Rohde, 1982) 
Table 1. Latitudinal gradients in numbers of monogenean and trematode genera of commercial marine fishes. (Data from Lebedev, 1969)*

\begin{tabular}{|c|c|c|c|}
\hline \multirow[t]{2}{*}{ Biogeographical zone } & \multirow{2}{*}{$\begin{array}{l}\text { Number of species of } \\
\text { commercial fish }\end{array}$} & \multicolumn{2}{|c|}{ Number of genera } \\
\hline & & Monogenea & Digenea \\
\hline Arctic & approx. 20 & 15 & 12 \\
\hline North-boreal & $40-50$ & 20 & 50 \\
\hline South-boreal & $>50$ & 50 & 160 \\
\hline Tropical & $100-120$ & 95 & 300 \\
\hline North-antiboreal & $40-50$ & 40 & 80 \\
\hline South-antiboreal plus Antarctic & approx. 20 & 3 & 10 \\
\hline \multicolumn{4}{|c|}{$\begin{array}{l}\text { Parasites of tropical fish are much less well known than those of fish from higher latitudes and } \\
\text { since } 1969, \text { when this table was composed, many new genera of Digenea and Monogenea have } \\
\text { been described from tropical oceans }\end{array}$} \\
\hline
\end{tabular}

1937, 1951; Darlington, 1957). Polyansky (1961, Russian edition, 1958) gave a brief discussion of the zoogeography of parasites of marine fishes in the USSR, and Delyamure (1968) included a detailed account of zoogeography in his monograph on helminths of marine mammals. A number of mainly Russian and American parasitologists have worked on the zoogeography of various marine parasite groups, but only recently has a brief review on major aspects of marine parasite zoogeography been published (Rohde, 1982). The following account attempts to give a concise but up-to-date review of the geographical distribution shown by marine parasites. Also discussed are examples to show the use of marine parasites as biological tags.

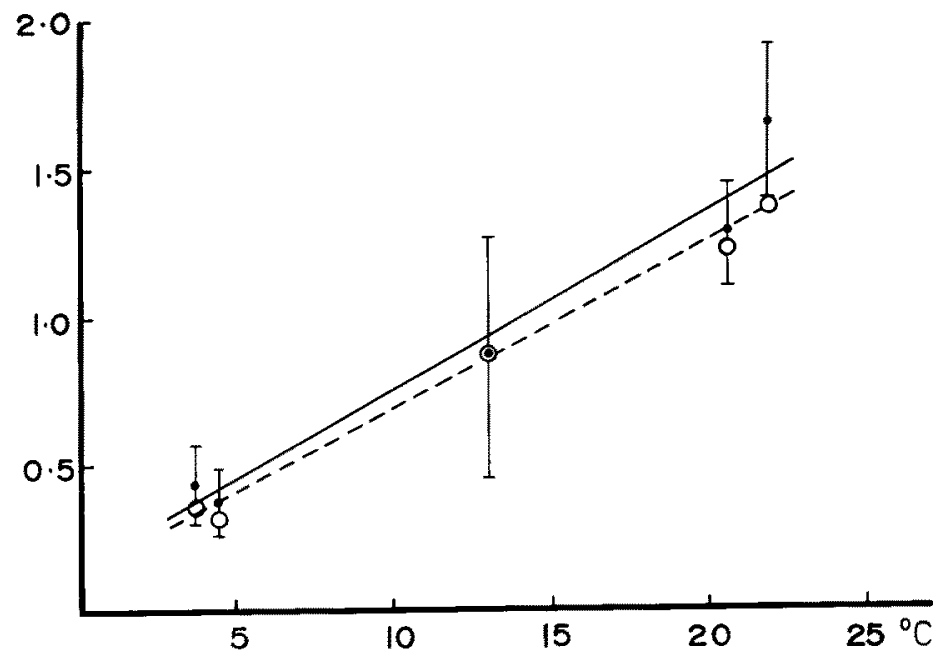

Fig. 2. Relative species diversity (average number of species of gill Monogenea per host species) of teleosts in the Atlantic. Open circle: total number of monogenean species/total number of host species examined at each locality. Closed circle: = above, but species occurring in $\times$ host species counted $x$ times. Ordinate: mean numbers of monogenean species per host species. Abscissa: means of annual sea surface temperature ranges in ${ }^{\circ} \mathrm{C}$ (Redrawn after Rohde, 1980b) 


\section{RESULTS AND DISCUSSION}

\section{Latitudinal gradients in species diversity}

Most groups of animals, whether terrestrial, freshwater or marine, show an increase of species numbers from high to low latitudes. Marine teleosts illustrate this phenomenon well (Fig. 1). Among marine parasites, latitudinal gradients in diversity with an increase in diversity towards the Equator, greater than that of their hosts, have been shown for genera of Monogenea and Digenea (Table 1) and for species of Monogenea (Fig. 2). Although there are more species of Digenea in warm than in cold waters associated with the much greater number of host species, a relatively greater number of digenean than of host species has not yet been demonstrated.

Maximum species numbers of Monogenea per host species also increase towards the Equator, whereas those of Digenea fluctuate greatly but are similar at all latitudes (Fig. 3).

Reversed diversity gradients are shown by helminth parasites of pinnipeds and cetaceans which have the greatest species numbers in the boreal region (Table 2).

Table 2. Helminth species of pinnipeds and cetaceans at different latitudes.

(Data from Dogiel ${ }_{r}$ 1964)

\begin{tabular}{|cccccc|}
\hline $\begin{array}{c}\text { Biogeographical } \\
\text { zone }\end{array}$ & Trematodes & Cestodes & Nematodes & $\begin{array}{c}\text { Acantho- } \\
\text { cephalans }\end{array}$ & Total \\
\hline Arctic & 6 & 7 & 9 & 3 & 25 \\
Boreal & 30 & 24 & 31 & 9 & 94 \\
Tropical & 7 & 2 & 18 & 4 & 31 \\
Antiboreal & 0 & 9 & 21 & 8 & 38 \\
Antarctic & 1 & 7 & 5 & 1 & 14 \\
\hline
\end{tabular}

Delyamure (cited by Dogiel, 1964) assumed that this is due to the reduced population density of hosts in warm waters, but an alternative explanation is that hosts and parasites have originated in cold waters and had more time to acquire parasites in that environment (Rohde, 1982). A greater species richness in cold waters has also been demonstrated for piscivorous leeches. According to Epshtein (1970), there are 45 species of Hirudinea belonging to 24 genera in the arctoboreal region, and only 13 species belonging to 5 genera in the tropical Atlantic. Probably associated with the greater number of species of leeches, which are vectors of blood protozoans, the highest prevalence of haematozoa of marine fishes from the Northwest Atlantic Ocean is found in the cold Labrador area (various authors, see Khan \& Newman, 1982). "The overall trend indicates increasing numbers of infected species and higher prevalence of hematozoan infections with increasing distance north of the Equator."

The much greater number of studies in northern cold-temperate waters explains the impressive numbers of exceptions to the rule of diversity increase in warm regions. However, all groups which do not conform to the rule are small representing only a minute proportion of marine parasites, and the overall trend appears to be one of increasing diversity towards the Equator and sometimes even of a r la t i vely greater increase compared with host groups. 
Fig. 3A. Maximum number of helminth species (mean of 3 fish species with largest species numbers) at different latitudes. $\times$ Trematoda in surface waters, $*$ Trematoda in deep water, 0 Monogenea in surface water, $\bullet$ Monogenea in deep water. Adult Trematoda in Atlantic. From right to left: (1) Gabon to Mauretania, West Africa acc. to Fischthal (1972) (Pomadasys jubelini, Trachinotus glaucus, Galcoides decadactylus); (2) Belize acc. to Fischthal (1977) (Haemulon flavolineatum, Lutjanus synagris, Calamus bajonado); (3) Tortugas Florida acc. to Manter (1947) (Haemulon plumieri, H. sciurus, Calamus calamus); (4) Tortugas Florida, deep water acc. to Manter (1934) (Urophycis regius, Merluccius sp., Brotula barbata); (5) Bimini, British West Indies acc. to Sogandares-Bernal (1959) (Haemulon sciurus, Holocentrus ascensionis, Haemulon album); (6) Off New York Bight, deep water acc. to Campbell et al. (1980) (Coryphaenoides armatus, Antimora rostrata, Coryphaenoides carapinus); (7) Black Sea acc. to Osmanov (1940) (Trachurus trachurus, Onos tricirrata, Crenilabrus pavo); (8) Britain acc. to Dawes (1947) (Gadus merlangus, Conger conger, Pleuronectes platessa); (9) Canada West Coast acc. to Margolis \& Arthur (1979) (Hippoglossus hippoglossus, Hippoglossoides platessoides, $H$. elassodon) $(10)$ Greenland acc. to Brinkmann (1975) (Anarhichas minor, A. Jupus, A. latifrons); (11) White Sea acc, to Shulman \& Shulman-Albova (1953) (Anarhichas lupus, Myoxocephalus scorpius, Pleuronectis flesus); (12) Barents Sea acc. to Polyansky (1966) (Anarhichas lupus, A. minor, Myoxocephalus scorpius). Monogenea in Atlantic. From right to left: (1) Brazil Sao Paulo State acc. to Rohde (unpubl) (Oligoplites saliens, Caranx latus, Scomber japonicus, all gills only); (2) Gulf of Mexico acc. to Hargis (1954, 1957) (Brevoortia patronus, Scomberomorus maculatus, Mugil cephalus); (3) Tortugas Florida, deep water acc. to Manter (1934) (Helicolenus dactylopterus, Epinephelus niveatus, Pontius longispinus); (4) Mar del Plata, Argentina acc. to Rohde (unpubl.) (Micropogon furnieri, S, japonicus, Prionotus punctatus, all gills only); (5) Off New York Bight, deep water acc. to Campbell et al. (1980) (Antimora rostrata, Alepocephalus agassizi, Coryphaenoides rupestris); (6) Black Sea acc to Osmanov (1940) (Sciaena umbra, Caspialosa pontica, Belone acus); (7) Britain acc. to Dawes (1947) (Trigla Iucerna, Merluccius merluccius, Gadus merlangus); (8) Canadian west coast acc. to Margolis \& Arthur (1979) (Hippoglossus hippoglossus, Xiphias gladius, Gadus morhua); (9) Norway acc. to Brinkmann (1952) (G. merlangus, Xyphias gladius, Molva molva); (10) Greenland acc. to Brinkmann (1975) (Hippoglossus hippoglossus, Reinhardtius hippoglossoides); (11) White Sea acc. to Shulman \& ShulmanAlbova (1953) (Boreogadus saida, Pleuronectes flesus, Liopsetta glacialis); (12) Barents Sea acc. to Polyansky (1966) (Mallotus villosus, Pollachius virens, Gadus morhua)

Fig. 3B. Trematoda in Indo-Pacific. From right to left: (1) Gulf of Panama acc. to Sogandares-Bernal (1959) (Epinephelus analogus, Kyphosus elegans, Seriola mazatiana); (2) Galapagos and coast Ecuador to Mexico acc. to Manter (1940) (Cheilichthys annulatus, Paranthias furcifer, Trachinotus rhodopus); (3) Hawaii acc. to Yamaguti (1970) (Neothunnus macropterus, Parathunnus sibi, Euthynnus yaito); (4) New Zealand acc. to Manter (1954b) (Leptocephalus conger, Notothenia macrocephala, Helicolenus percoides); (5) New Zealand acc. to Hewitt \& Hine (1972) (Conger verreauxi, Cyttus australis, Chelidonichthys kumu); (6) Sea of Japan acc. to Zhukov (1960a) (Myoxocephalus brandti, Hemitripterus villosus, Sebastodes trivittatus); (7) Sub-Antarctic to Antarctic acc. to Prudhoe \& Bray (1973) (Champsocephalus gunnari, Notothenia cyanobrancha, Trematomus newnesi); (8) Canadian east coast acc. to Margolis \& Arthur (1979) (Sebastes alutus, S. pinniger, Syngnathus griseolineatus) (9) Eastern Kamchatka acc. to Strelkov (1960) (Lepidopsetta bilineata, Limanda aspera, Myoxocephalus jaok). Monogenea in Indo-Pacific. From right to left: (1) Queensland and Papua New Guinea acc. to Rohde (unpubl.) (Epinephelus tauvina, Lethrinus chrysostomus, L. nebulosus, all gills only); (2) New South Wales acc. to Roubal (1981) and personal communication, Roubal et al. (1983), Rohde, (unpubl.) (Acanthopagrus australis; Chrysophrys auratus, Euthynnus alletteratus); (3) New South Wales deep water acc. to Rohde (unpubl.) (Hygophum hygomi, Myctophum phengodes, Synagrops japonicus); (4) South Australia acc. to Rohde (unpubl.) (Acanthopagrus butcheri, Platycephalus richardsoni and Aldrichetta forsteri); (5) New Zealand acc. to Hewitt \& Hine (1972) (Trachurus novaezelandiae, Thyrsites atun, Seriolella brama acc. to Rohde et al. 1980); (6) Canadian east coast acc. to Margolis \& Arthur (1979) (Sebastes alutus, S. caurinus, $S$. zacentrus); (7) Chukotsk Peninsula acc, to Zhukov (1960b) (Eleginus gracilis, Pleuronectes stellatus,

$$
\text { Clupea harengus) }
$$



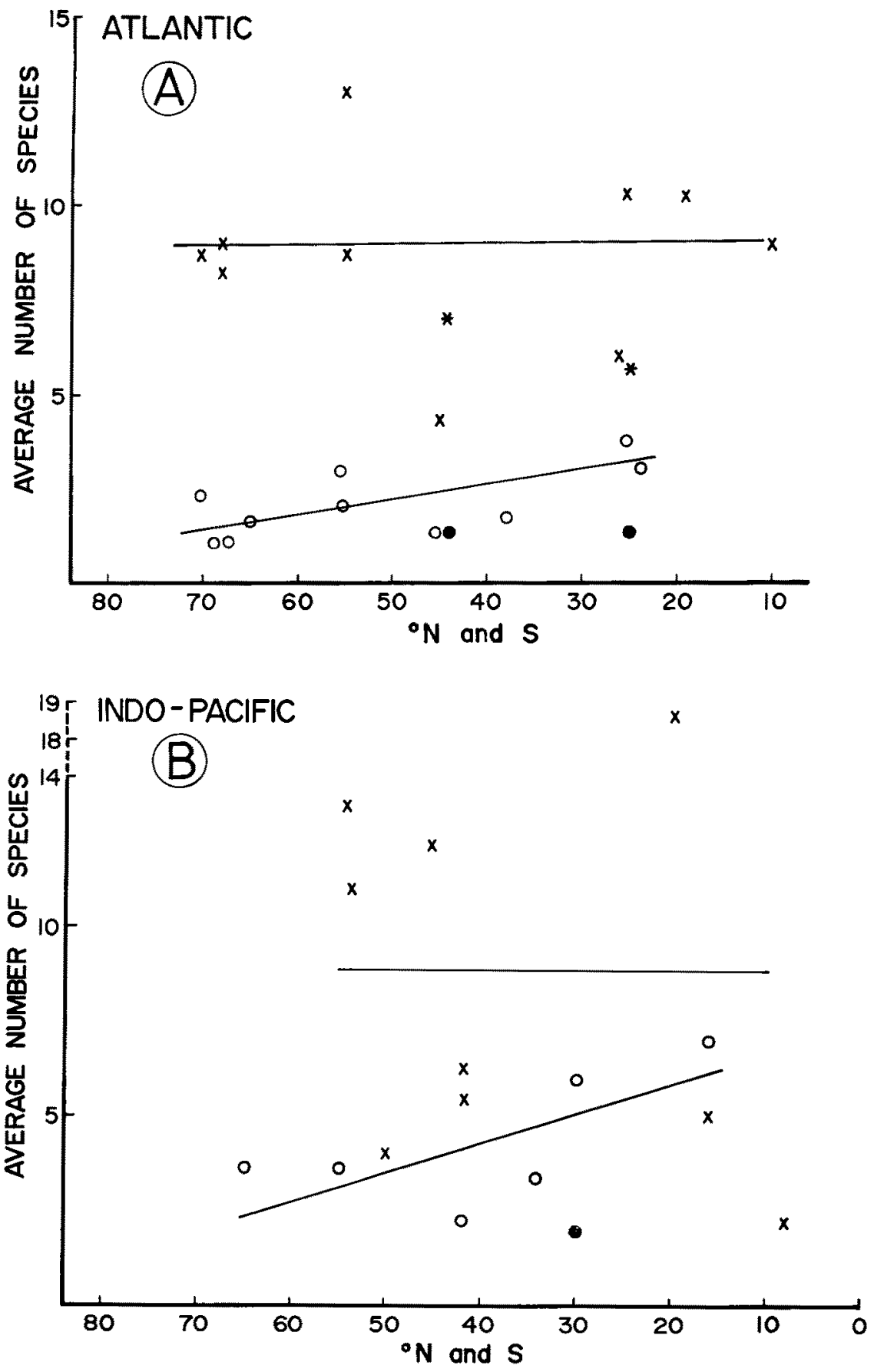


\section{Differences between the Atlantic and Indo-Pacific}

Most groups of free-living animals have greater species richness in the Indo-Pacific than in the Atlantic Ocean (see Fig. 1 for marine teleosts). Data for some major parasite groups indicate the same. For example, Parukhin (1975) examined 6500 fish of 200 species belonging to 100 families from various regions and concluded that species numbers of nematodes are smaller in the southern Atlantic than in the Indo-Pacific. The same was shown for Monogenea by Rohde (1980b). The black bream, Acanthopagrus australis, on the Australian east coast, has nine species of Monogenea (Roubal, 1981; and pers. comm.), and the snapper, Chrysophrys auratus, from the same locality has six (Roubal et al., 1983). Such large species numbers are not known from Atlantic fish.

The two ocean systems also differ in the species composition of their parasite faunas as indicated by numerous endemic species. A consequence of greater diversity, endemicity of trematode and monogenean genera is greater in the Indo-Pacific than the Atlantic (Lebedev, 1969; Tables 3 and 4) and endemicity of species is much greater than

Table 3. Endemicity of genera of Digenea in the Atlantic and Indopacific Oceans.

(Data from Lebedev, 1969)

\begin{tabular}{|lcc|}
\hline & No. in Atlantic & No. in Indopacific \\
\hline In 1 region & $78(36 \%)$ & $182(57 \%)$ \\
In 2 regions & $136(64 \%)$ & $136(43 \%)$ \\
Total & 214 & 318 \\
\hline
\end{tabular}

Table 4. Endemicity of genera of Monogenea in the Allantic and Indo-Pacific Oceans.

(Data from Lebedev, 1969)

\begin{tabular}{|lrr|}
\hline & No. in Atlantic & No. in Indopacific \\
\hline In 1 region & $40(42 \%)$ & $114(67 \%)$ \\
In 2 regions & $56(58 \%)$ & $56(33 \%)$ \\
Total & 96 & 170 \\
\hline
\end{tabular}

that of genera (see review in Rohde, 1982). Thus, according to Manter $(1940,1947,1955)$, of 147 shallow water trematodes at Tortugas, Florida, only 26 species (17.6\%) occurred also in the Pacific, and of the 62 species on the Atlantic side of Central America, and the 31 species in the Gulf of Panama, only 5 species occurred in both regions (SogandaresBernal, 1959). Nevertheless, according to Sogandares-Bernal, until 1959 the impressive number of 41 trematode species had been found both in the American Atlantic and Pacific.

The number of helminth species common to the cold northern Atlantic and Pacific is surprisingly high. According to Strelkov (1960), eastern Kamchatka has 51 known species of trematodes, cestodes, nematodes and acanthocephalans, and the Barents Sea has 70 . Thirty-four species occur in both regions. Of the 57 species recorded from the 


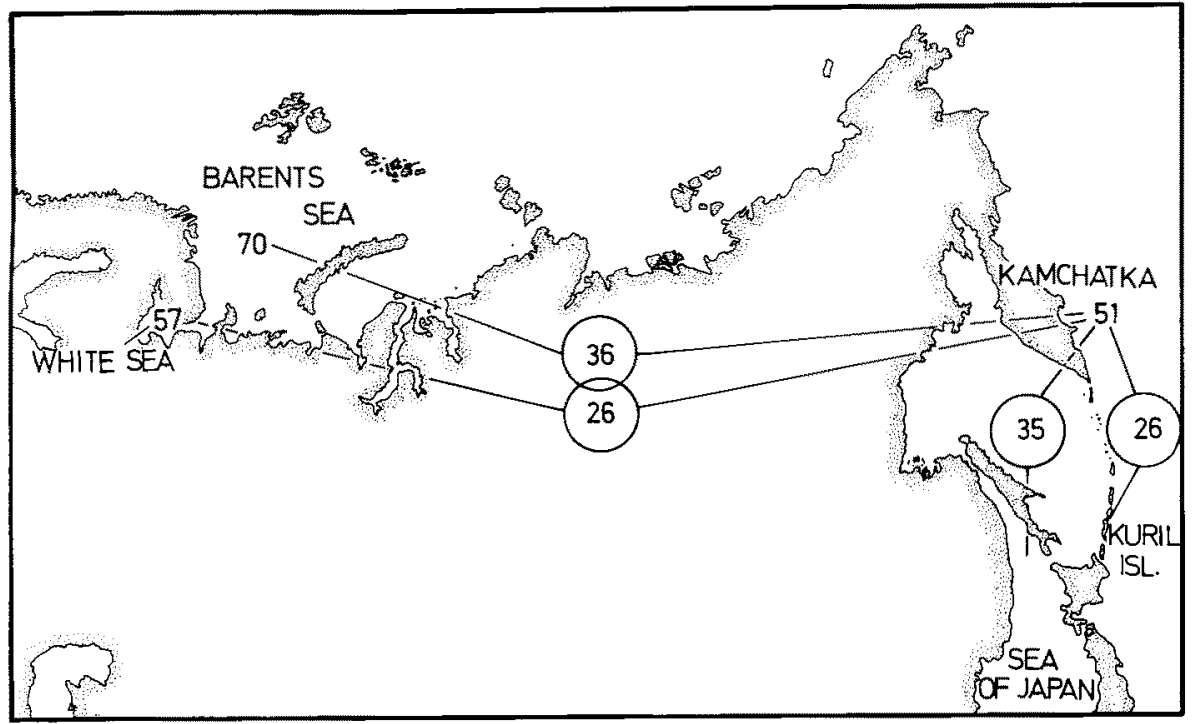

Fig. 4. Number of helminth species in the White and Barents Seas and the northwestern Pacific. Numbers in circles indicate species shared by two regions. (Data from Stelkov, 1960)

White Sea, 26 species are also known from eastern Kamchatka. The proportion of helminths shared is similar to the proportion shared by adjacent Pacific seas. Thus, of the 51 species from eastern Kamchatka, 35 are also known from the northwestern Sea of Japan and 26 also from the South Kuril Islands (Fig. 4) (see also Zhukov, 1960a). Exchange of species may have occurred during the warm Interglacials.

It is of particular interest that a comparatively much smaller number of fish species is shared by the northern Atlantic and Pacific, and endemicity of fish in the northern Pacific is much greater than that of their parasites (Table 5). Thus, there are no less than 21

Table 5. Distribution of shelf fishes in the Arctic and northern temperate regions.

(Data from Ekman, 1953)

\begin{tabular}{|lrr|}
\hline \multicolumn{1}{|c}{ Regions } & Species & Genera \\
\hline In North Pacific including adjacent Polar Sea & $550(76 \%)$ & $230(69 \%)$ \\
In North Atlantic including adjacent Polar & $150(21 \%)$ & $51(15 \%)$ \\
Sea & $25(3 \%)$ & $54(16 \%)$ \\
In both regions & 725 & 335 \\
Total & & \\
\hline
\end{tabular}

families of endemic fish in the north Pacific, whereas the north Atlantic has not a single one (review by Ekman, 1953). One reason for the differences between hosts and parasites may be the relatively slower evolution of parasites which has not permitted the differentiation in the two regions of as many taxa of parasites as of hosts. Another reason may be the possible transfer over wide distances of many parasites which use intermediate hosts 
or have encysted stages and are not strictly host specific. The latter explanation can be excluded for the strictly host-specific and directly developing Monogenea, According to Zhukov (1960b), of the 22 species of marine Gyrodactylidae known from the northern Pacific and 21 species known from the northern Atlantic, 14 species are shared by both regions. The taxonomic review by Malmberg (1970) shows that several of Zhukov's species must be separated into more than one species. Hence, endemicity is probably slightly greater than assumed by Zhukov. However, Gyrodactylidae are notoriously difficult and Pacific forms are insufficiently known. Nevertheless, the data available so far indicate that endemicity of monogenean species in the northern seas is not significantly greater than that of endoparasites with indirect development. However, more studies are needed.

Latitudinal gradients in prevalence and intensity of infection, host range and specificity, and fluctuations of infections

Few studies on the latitudinal gradients of infection prevalence and intensity have been made. Rohde (1977) examined them for gill monogeneans. He found a great variability of infection intensities at all latitudes, but no definite changes with latitude. Prevalence of infection, on the other hand, appears to be greater in warm seas (Fig. 5).

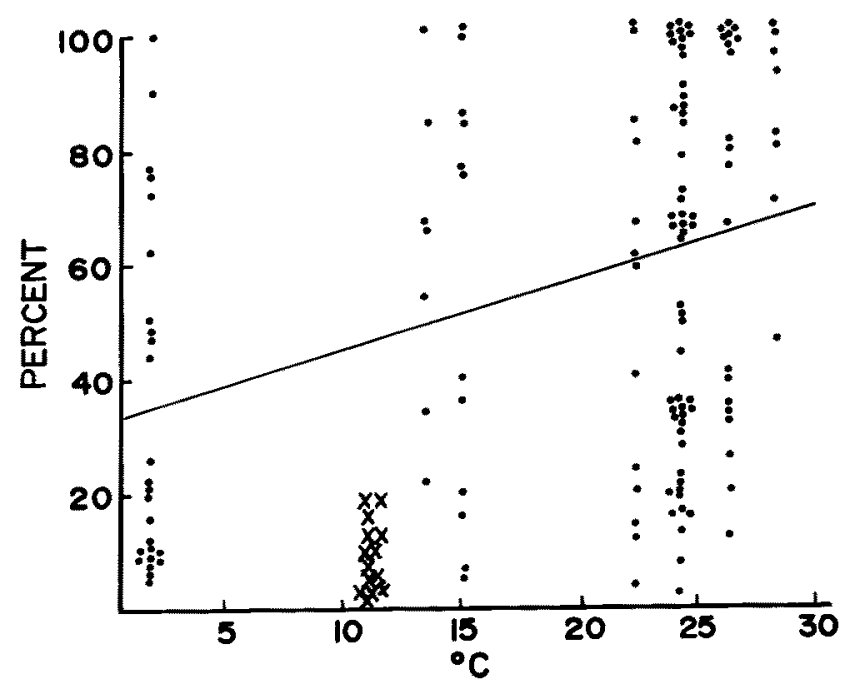

Fig. 5. Frequencies (prevalence) of infection with gill Monogenea of marine teleosts at different latitudes in the Pacific. Fish species without gill Monogenea not included. and regression line: surface fish. $\times$ deepwater fish off the N.S.W. coast $(\%)$. Ordinate: prevalence of infection $(\%)$.

Abscissa: means of annual sea surface temperature ranges $\left({ }^{\circ} \mathrm{C}\right)$

This is apparently not a result of reduced or absent seasonality, as deep water monogeneans also have a low prevalence of infection (Rohde, unpubl.; Fig. 5).

Host ranges of Monogenea are very small and similar at all latitudes (Fig. 6). Trematodes have more restricted host ranges in warm than in cold waters (Manter 1947. 1955; Rohde 1978c). Host specificity indices based on prevalence (frequency) of infection also show a latitudinal gradient for trematodes (Fig. 7). However, if specificity indices 


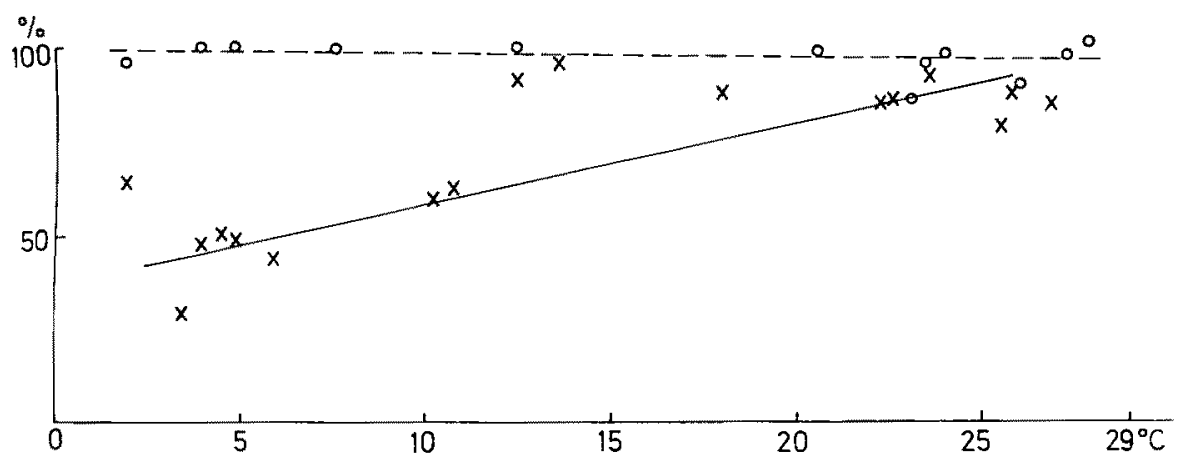

Fig. 6. Host ranges of marine Monogenea (circles) and Trematoda (crosses) at different latitudes. Ordinate: percentages of species parasitizing one and two host species. Abscissa: means of annual sea-surface temperature ranges. After Rohde (1980a) with additional data from one trematode survey by Zhukov (1976)

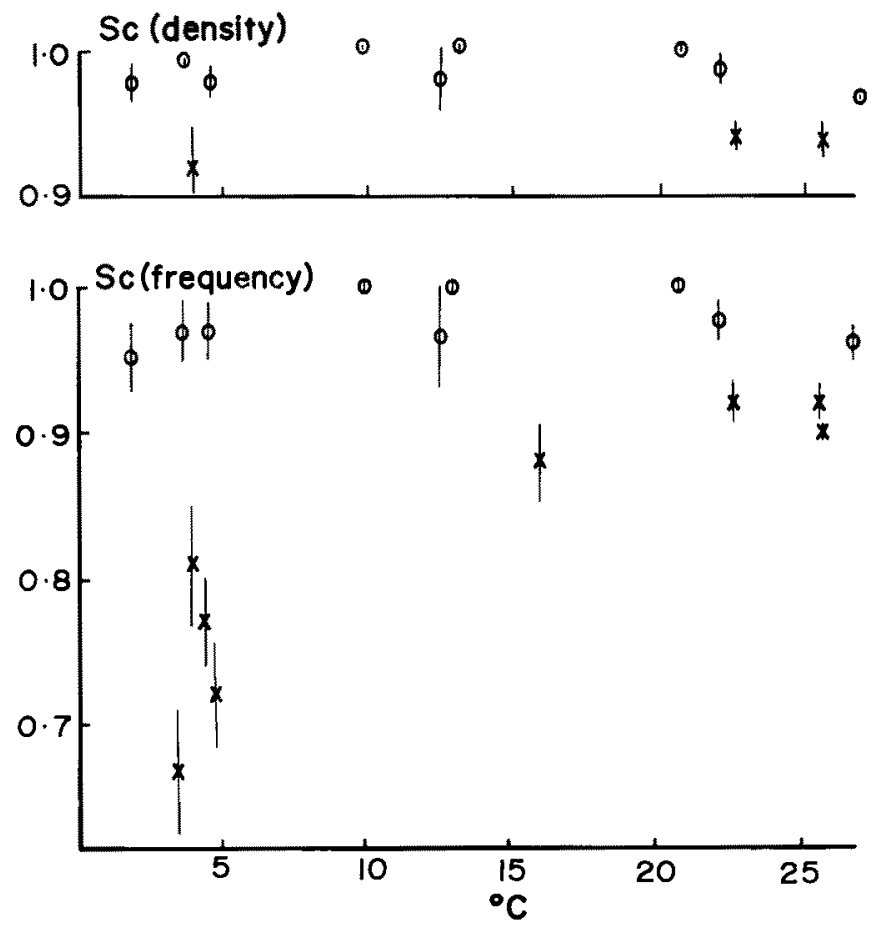

Fig. 7. Host specificitiy indices of marine Monogenea (circles) and Trematoda (crosses) at different latitudes. Ordinate: Host specificity indices based on density or frequency of infection. Abscissa: means of annual sea surface temperature ranges in ${ }^{\circ} \mathrm{C}$ (Redrawn after Rohde, 1980c)

based on density (intensity) of infection are used, a latitudinal gradient is not apparent. The reason is that although trematodes infect more host species and many of them frequently in cold seas, only one or a few are usually heavily infected. Sufficient data, however, are available only for the White Sea and more studies are needed to support this conclusion. Other parasite groups have not been analyzed in this respect. 
With regard to fluctuations of parasitic infections, numerous studies in cold-temperate seas have shown that such fluctuations are common but not universal (see review in Rohde, 1982). Very few studies in tropical and subtropical waters have been made and conclusions concerning the existence of latitudinal gradients cannot at present be drawn.

\section{Differences between shallow and deep water}

Rohde (1982) reviewed the evidence for vertical gradients in parasites of marine fish based on the surveys of several authors. He summarized, partly following Noble (1973), that midwater fishes examined have far fewer species and numbers of parasites than inshore and open ocean surface fishes. There are very few adult helminths. In order of abundance the parasites are: larval nematodes, myxozoans, larval cestodes, copepods and larval trematodes of the family Hemiuridae. The parasite fauna becomes poorer with depth until the benthopelagic zone is reached. Bottom dwelling fishes have more species and greater numbers of parasites than midwater species, because their food probably includes more infected intermediate hosts, and also because they are larger and have a longer life span. However, more studies are needed to clarify whether these generalizations hold for all latitudes. The difference in diversity of parasitic species between surface and deep water pelagic fish apparently exists only in regions where the surface waters are warm. It would be of special interest to compare deep sea parasite faunas in tropical and cold-temperate zones on the basis of surveys as large as that by Campbell et al. (1980).

The findings of Campbell et al. (1980) and my own unpublished data of a survey of deepwater fish off the New South Wales coast in eastern Australia (approximately 900 fish of 30 species) appear indeed to indicate that at least some of the general trends observed in cold water fish are also found in deep water fish. Thus, maximum species numbers per fish species of trematodes and monogeneans are similar, and prevalence of infection with monogeneans is low and roughly similar in both groups (Fig. 5). However, my survey is not yet completed and so far mainly small pelagic fish have been examined. Inclusions of larger benthic fish may well make the data even more similar to those for cold water surface fish. $B$. Heath is working on the endoparasites of these fish.

\section{Parasite endemicity at remote oceanic islands}

Remote oceanic islands, i.e. islands 300 miles or more from the nearest continent, were shown to have a low endemicity of their fauna in the north and middle Atlantic, a greater endemicity in the southern Atlantic and Pacific, and a very high endemicity in sub-Antarctica (Briggs, 1966). Briggs explained this by a longer undisturbed evolutionary history of the islands with high endemicity. Pleistocene temperature reductions apparently were most marked in the northern and middle Atlantic $c_{z}$ where they wiped out much of the original fauna. Manter (1967) found that endemicity of trematodes corresponds to that of other animals, and the scanty data for Monogenea appear to follow the same trend (Rohde, 1982) (Table 6). 
Table 6. Endemicity of marine fishes and their parasites at oceanic islands according to Rohde (1982)

\begin{tabular}{|c|c|c|c|}
\hline Areas & Fishes & $\begin{array}{l}\text { Endemicity of } \\
\text { Trematodes }\end{array}$ & Monogenea \\
\hline \multicolumn{4}{|l|}{ North Atlantic } \\
\hline Azores & $0 \%$ & $?$ & $?$ \\
\hline Madeira & $3 \%$ & $?$ & $?$ \\
\hline Bermuda & $5 \%$ & $2 \%$ (1 of 43 species) & $?$ \\
\hline Cape Verde & $4 \%$ & $?$ & $?$ \\
\hline \multicolumn{4}{|l|}{ South Atlantic } \\
\hline St. Helena & $27-50 \%$ & $?$ & $?$ \\
\hline Tristan da Cunha & $23 \%$ & $?$ & $?$ \\
\hline \multicolumn{4}{|l|}{ Pacific } \\
\hline Galapagos Islands & $15-27 \%$ & $61 \%$ (of 80 species) & (6 of 11 species) \\
\hline Hawaii & $34 \%$ & $74 \%$ (of 92 species) & $88 \%$ (128 of 146 species) \\
\hline Easter Island & $29 \%$ & $?$ & $?$ \\
\hline Lord Howe Island & $22 \%$ & $?$ & $?$ \\
\hline $\mathrm{Fiji}$ & $?$ & $56 \%$ (of 35 species) & $?$ \\
\hline New Caledonia & $?$ & $45 \%$ (of 33 species) & $?$ \\
\hline
\end{tabular}

Importance of temperature for parasite distribution

Temperature appears to be the major single factor responsible for the geographical distribution of marine organisms. It affects faunas by increasing diversity in warm seas and by bringing about differences in the species composition of faunas. Rohde (1978b) has shown that temperature is indeed the decisive factor responsible for species numbers, since habitats which are identical in all other characteristics but temperature, support different numbers of parasite species at different latitudes. Such habitats are the gills and the body surface of marine fishes. Rohde $(1978 \mathrm{a}, \mathrm{b})$ explained increased diversity in warm environments by an accelerated speed of evolution at high temperatures, probably due to shorter generation times, faster selection and possibly faster mutation rates.

Rohde (1982) reviewed the evidence for temperature being the major factor that determines species composition. Several surveys have shown that helminth species from cold seas are also found, but very rarely, in warmer waters, and vice versa. Thus, Zhukov (1960a) found 87 species of endoparasitic helminths in the cold northwestern Sea of Japan. Many of these have also been recorded from other cold waters in the Atlantic and Indo-Pacific, but only two from the warmer southwestern part and two from the southeastern part of North America.

The cosmopolitan trematode species Derogenes varicus is known from a large number of fish species in cold and temperature surface waters, but at low latitudes it occurs only in deeper cold water or in regions with cold currents (e.g. the Galapagos Islands, Manter, 1955). Finally, species from cold deepwater at low latitudes frequently show distinct affinities with surface species from higher latitudes, but not with surface species from the same locality. Thus, according to Manter (1955), only 5 of 49 trematode 
species from deep water at Tortugas, Florida, were also found in nearby surface water, whereas the most common genera occur also in the northern Pacific and Atlantic, in deeper waters at low latitudes, and in the Tasmanian and New Zealand regions.

\section{Effects of host migration on parasites (parasites as biological tags)}

Parasites have repeatedly been used to study fish migrations. Prerequisites for the usefulness of parasites for this purpose are that they have a long life span and that infection is restricted to certain areas (Margolis, 1965). Parasites which are lost during migration cannot be used. Margolis $(1963,1965)$ demonstrated that two species of endoparasitic helminths are excellent indicators of the geographical origin of sockeye salmon, Oncorhynchus nerka. The plerocercoid larva of Triaenophorus crassus is restricted to some lakes of western Alaska, and extensive sampling over a period of five years confirmed that the parasite occurs only in downstream migrant sockeye from these lakes and in adults returning to them. The nematode Dacnitis truttae, on the other hand, is found only in some sockeye salmon from rivers of the east and west coasts of Kamchatka. Extensive sampling failed to find it in fish from North America. Both parasites have a long life span, as indicated by the presence of the first species in returning adult salmon, and by the occurrence of the second species in fish which have spent as much as four years at sea. Sampling at sea showed that maturing and immature salmon from western Alaska are extensively distributed to the east and west of their area of origin, with maximum migrations of 1100 to 1200 miles. Maturing Kamchatkan salmon migrate 500 to 700 miles eastward from their area of origin, and immature fish up to 1100 to 1200 miles (Fig. 8). In addition, certain oceanic areas are dominated by maturing fish of certain stocks with different prevalence of Triaenophorus infection as characteristic for certain streams. Comparisons of incidence of infection in schools from different river systems in western Alaska with that of returning salmon showed that there is no or hardly any straying, "even between streams whose mouths are only a few miles apart" (Margolis, 1965).

\section{Parasites as indicators of the geographical origin of hosts}

Von thering $(1891,1902)$ was the first to use parasites and ectocommensals to clarify relationships of hosts, as well as places of origin, dispersal of hosts, and ancient land connections between land masses. The method is therefore called the von thering method. An important assumption for this method is that animals have a greater diversity in areas where they have been for a long time than in those into which they have recently immigrated. Few marine parasites have been used in this respect.

Mamaev et al. (1959) and Margolis (1965) pointed out that Pacific salmonids have many freshwater parasites specific to them, some with complex life cycles, but no marine endoparasites. Only two ectoparasites specific to salmonids are marine, a monogenean and a copepod. The authors concluded that salmonids must be of freshwater origin, an assumption also supported by other evidence, although until recently some ichthyologists believed in a marine origin of the group (see "Discussion" and "References" in Margolis, 1965).

Another example is the controversy about the geographic origin of the southern 


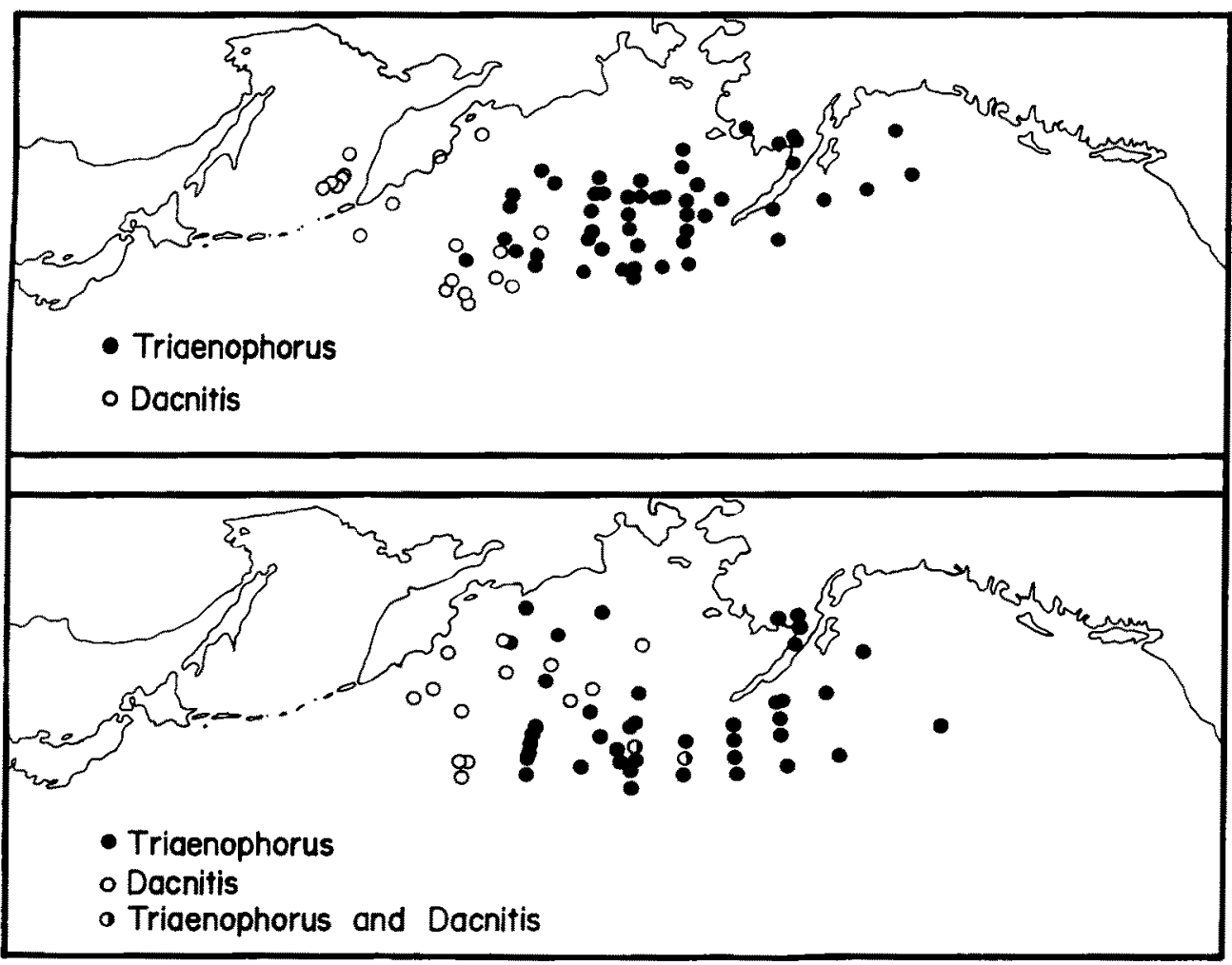

Fig. 8. Distribution of sockeye salmon infected with Triaenophorus and Dacnitis. Top: maturing fish. Bottom: immature fish (Redrawn after Margolis, 1965)

hake, Merluccius hubbsi (Gadiformes) distributed along the Argentinian coast (Fig. 9). It shows the importance of accurate and extensive taxonomic studies to avoid wrong conclusions. $M$. hubbsi had been thought to have evolved from $M$. merluccius or $M$. bilinearis in the north Atlantic, but according to Szidat (1961), its parasites are similar to those of the north Pacific hake $M$. productus and unlike those in the Atlantic. The same parasite fauna was found in three other gadiforms from the Argentinian coast, i.e. Macruronus magellanicus, Micromesistius australis and Salilota australis, whereas a fourth, Urophycis brasiliensis, had a typically Atlantic parasite fauna. Szidat concluded that the last species immigrated from the northern Atlantic, presumably through deep water along the American east coast, whereas the other four came from the southern Pacific. Kabata (1970) found a parasitic copepod on the Pacific coast of Canada which he considered to be conspecific with Szidat's Neobrachiella lageniformis known only from the Argentinian coast. This finding apparently supported Szidat's conclusion about the origin of M. hubbsi. However, Ho (1974) observed the same copepod on Atlantic hake on the coast of Florida, and according to the most recent review of Kabata \& Ho (1981), there are three forms of Neobrachiella insidiosa (Heller, 1865), i.e. N. insidiosa f. insidiosa Kabata, 1979 on Merluccius merluccius; $N$. insidiosa f. lageniformis Kabata, 1979 on Merluccius hubbsi off Argentina, on $M$. bilinearis off Florida and on $M$. australis in New 


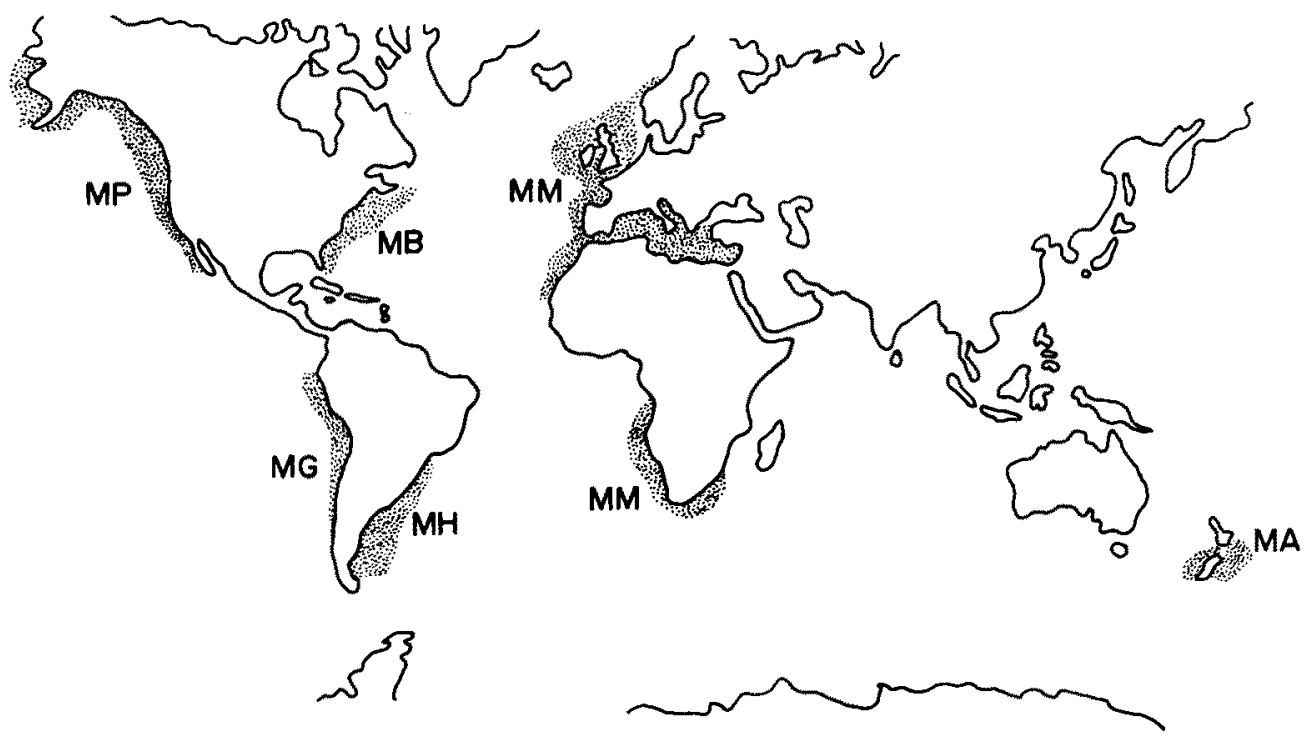

Fig. 9. Present distribution of the genus Merluccius (Redrawn after Kabata \& Ho, 1981). MA = $M$. australis $\mathrm{MB}=\mathrm{M}$. bilinearis; $\mathrm{MG}=\mathrm{M}$. gayi; $\mathrm{MH}=\mathrm{M}$. hubbsi; $\mathrm{MM}=\mathrm{M}$. merluccius; $\mathrm{MP}=$ M. productus

Zealand; and $N$. insidiosa f. pacifica Kabata, 1979 on Merluccius productus and M. gayi off the Canadian Pacific coast, California, Peru and Chile. Thus, the species originally described as Neobrachiella lageniformis is a form of Neobrachiella insidiosa restricted to Atlantic hake. Confusion had arisen because it closely resembles the eastern Pacific form in having large genital processes. The Pacific form, however, possesses a pair of posterior processes which are absent in younger adult females. Absence of these processes in young adults led to their identification as Neobrachiella lageniformis and the false conclusions concerning the Pacific origin of Merluccius hubbsi (Fig. 10).

A

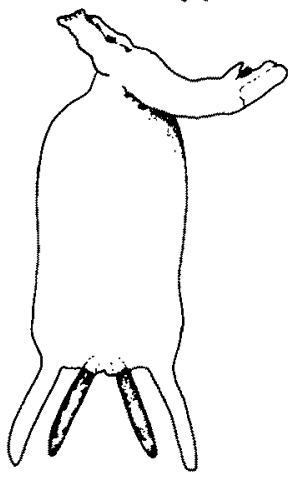

B

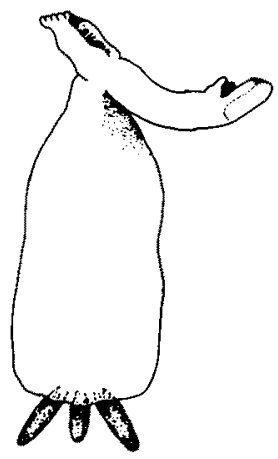

C

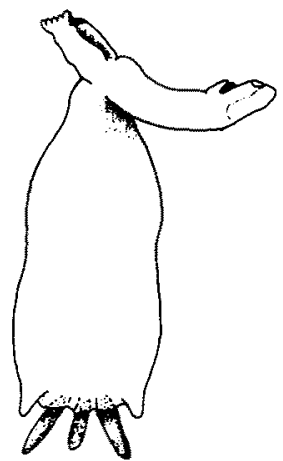

Fig. 10. Neobrachiella insidiosa. (A) f. insidiosa (B) f. lageniformis, (C) f. pacifica (Redrawn after Kabata \& Ho, 1981) 
Kabata \& Ho (1981) re-assessed the evidence from all copepod parasites of Merluccius for the origin of the group. "Acutely aware of the pitfalls with which the use of such tags is beset, they believed, nonetheless, that such tags can be used, at least as corroborative evidence, to solve many problems of fish biology, including some presented by the investigations of a phylogenetic and zoogeographical nature." They concluded that the genus Merluccius arose in the northern Atlantic and spread southward and into the Pacific through the gap between North and South America, and that $M$. hubbsi off Argentina immigrated along the east coast of South America (Fig. 11).

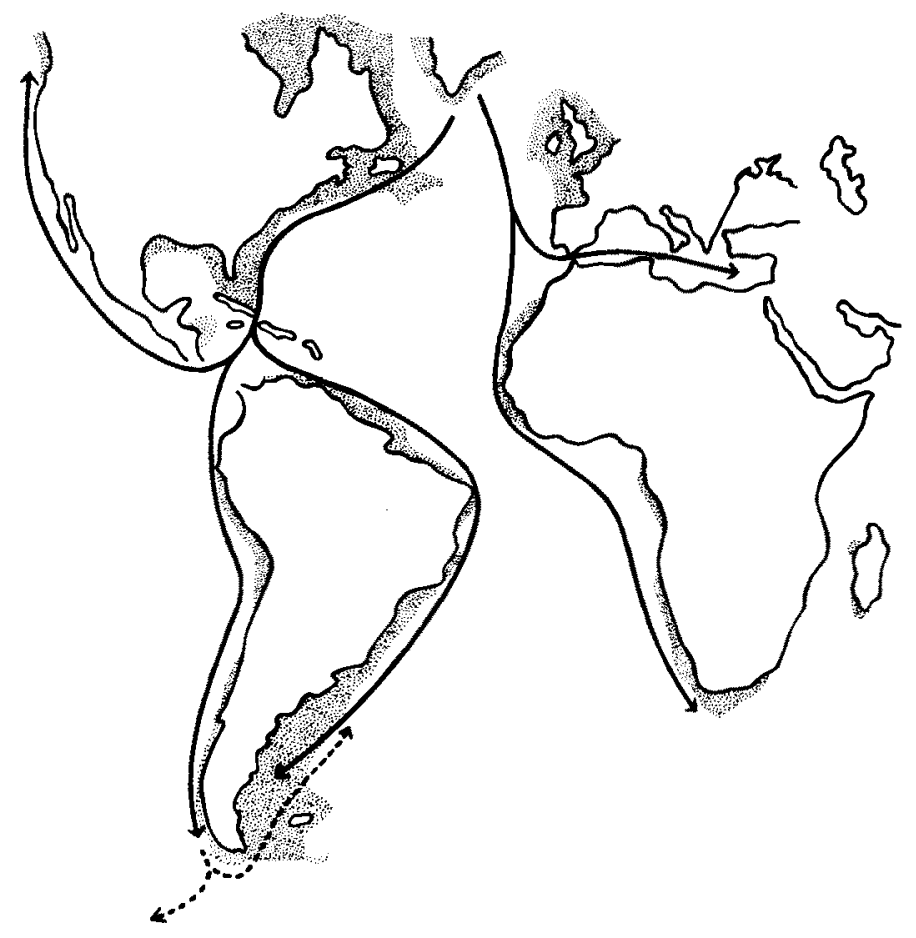

Fig. 11. Dispersal of the genus Merluccius according to Kabata \& Ho (1981). Interrupted lines indicate dispersal of $M$. hubbsi (Argentina) and $M$. australis (New Zealand) according to Inada (1981)

Reimer (1981), examining the trematodes of Merluccius, also concluded that Szidat's hypothesis is not supported by facts. In summary, paleontological and other ichthyological evidence as well as parasite data now firmly confirm the view that hake originated in the northern Atlantic (references in Kabata \& Ho, 1981). However, there is still some doubt on how $M$. hubbsi reached the South American Atlantic coast. Whereas Kabata \& Ho (1981) assume a southward migration along the South American east coast, the ichthyologist Inada (1981) suggests migration along the South American west coast after crossing the Central American gap (Fig. 11). 


\section{LITERATURE CITED}

Briggs, J. C., 1966. Oceanic islands, endemism, and marine paleotemperatures. - Syst. Zool. 15, 153-163.

Briggs, J. C., 1974. Marine zoogeography. McGraw Hill, New York, 475 pp.

Brinkmann, A. 1952. Fish trematodes from Norwegian waters I. The history of fish trematode investigations in Norway and the Norwegian species of the order Monogenea. - Arbok Univ.; Bergen (Naturvit. rekke) 1952 (1), 1-134.

Brinkmann, A., 1975. Trematodes from Greenland. - Meddr Grønland 205, 1-88.

Campbell, R. A., Haedrich, R. L. \& Munroe, T. A., 1980. Parasitísm and ecological relationships among deep-sea benthic fishes. - Mar. Biol. 57, 301-313.

Darlington, P. J., 1957. Zoogeography. The geographical distribution of animals. Wiley, New York, $675 \mathrm{pp}$.

Dawes, B., 1947. The Trematoda of British fishes. The Ray Society, London, $364 \mathrm{pp}$.

Delyamure, S. L., 1968. Helminthofauna of marine mammals (ecology and phylogeny). Israel Progr. Scient. Transl., Jerusalem, 522 pp. (Russ. ed. 1955).

Dogiel, V. A., 1964. General parasitology. Oliver \& Boyd, Edinburgh, 516 pp.

Ekman, S, 1935. Tiergeographie des Meeres. Akad. Verl.Ges., Leipzig, 512 pp.

Ekman, S., 1953. Zoogeography of the sea. Sidgwick \& Jackson, London, 417 pp.

Epshtein, V. M., 1970. Bipolar distribution of marine fish leeches (Hirudinea: Piscicolidae). In: AllUnion symposium on parasites and diseases of marine animals. - Izdat. "Naukova-Dumka", Kiev 1, 143-146.

Fischthal, J. H., 1972. Zoogeography of digenetic trematodes from West African marine fishes. Proc. helminth. Soc. Washington 39, 192-203.

Fischthal, $J . H$, 1977. Some digenetic trematodes of marine fishes from the Barrier Reef and reef lagoon of Belize. - Zool. Scr. 6, 81-88.

Hargis, W. J., 1954. Monogenetic trematodes of some Gulf of Mexico fishes. Ph.D. Thesis, Florida State University, $304 \mathrm{pp}$.

Hargis, W. J, 1957. The host specificity of monogenetic trematodes. - Expl. Parasit. 6, 610-625.

Hesse, R., 1924. Tiergeographie auf ökologischer Grundlage. Fischer, Jena, 613 pp.

Hesse, R., Allee, W. C. \& Schmidt, K. P., 1937. Ecological animal geography. 1st ed. Wiley, New York, $597 \mathrm{pp}$.

Hesse, R., Allee, W. C. \& Schmidt, K. P., 1951. Ecological animal geography. 2nd ed. Wiley, New York, $715 \mathrm{pp}$.

Hewitt, G. C. \& Hine, P. M., 1972. Checklist of parasites of New Zealand fishes and of their hosts. N. Z. Jl. mar. Freshwat. Res, 6,69-114.

Ho, J. S., 1974. Parasitic copepods as indicator of hake's (Merluccius) zoogeography. - Proc. int. Congr. Parasitol. 3, 1633-1634.

Ihering, $H$. von, 1891. On the ancient relations between New Zealand and South America. - Trans. Proc. N. Z. Inst. 24, 431-445.

Ihering, $H$. von, 1902. Die Helminthen als Hilfsmittel der zoogeographischen Forschung. - Zool. Anz. 26, 24-51.

Inada, T., 1981. Studies on the Merlucciid fishes. - Bull. Far Seas Fish. Res. Lab. 18, 1-172.

Kabata, Z., 1970. Diseases of fish I: Crustacea as enemies of fishes. T.F.H. Publ., Jersey City, 171 pp.

Kabata, Z. \& Ho, J. S., 1981. The origin and dispersal of hake (genus Merluccius: Pisces: Teleostei) as indicated by its copepod parasites. - Oceanogr. mar. Biol. 19, 381-404.

Khan, R. A. \& Newman, M. W. 1982. Blood parasites from fish of the Gulf of Maine to Cape Hatteras, Northwest Atlantic Ocean, with notes on the distribution of fish haematozoa, - Can.J. Zool. $60,396-402$.

Lebedev, B. I., 1969. Basic regularities in the distribution of monogeneans and trematodes of marine fishes in the world ocean (Russ.) - Zool. $\mathrm{Zh} .48,41-50$.

Malmberg, G., 1970. The excretory system and the marginal hooks as a basis for the systematics of Gyrodactylus (Trematoda, Monogenea). - Ark. Zool. (Ser. 2) 23, 1-235.

Mamaev, Yu. L., Parukhin, A. M., Baeva, O. M. \& Oshmarin, P. G, 1959. The helminth fauna of fareastern salmonids in connection with questions of local stocks and routes of migration of these fish. (Russ.) Maritime Book Publ, Vladivostok, 74 pp. 
Manter, H. W., 1934. Some digenetic trematodes from deep-water fish of Tortugas, Florida. - Pap. Tortugas Lab. 28, 257-345.

Manter, H. W., 1940. Digenetic trematodes of fishes from the Galapagos Islands and the neighboring Pacific. - Allan Hancock Fdn Publ. (Ser. 1) 2, 329-497.

Manter, H. W., 1947. The digenetic trematodes of marine fishes of Tortugas, Florida. - Am. Midl. Nat. $38,257-416$.

Manter, H. W., 1954. Some digenetic trematodes from fishes of New Zealand. - Trans. R. Soc. N. Z. $82,475-568$.

Manter, H. W., 1955. The zoogeography of trematodes of marine fishes. - Expl Parasit. 4, 62-86.

Manter, H. W., 1967. Some aspects of the geographical distribution of parasites. - J. Parasit. 53, 1-9.

Margolis, L., 1963. Parasites as indicators of the geographical origin of sockeye salmon, Oncorhynchus nerka (Walbaum), occurring in the North Pacific Ocean and adjacent seas. - Bull. int. N. Pacif. Fish. Commn. 11, 101-156.

Margolis, L., 1965. Parasites as an auxiliary source of information about the biology of Pacific salmons (genus Oncorhynchus), - J. Fish. Res. Bd Can. 22, 1387-1395.

Margolis, L. \& Arthur, J. R., 1979. Synopsis of the parasites of fishes of Canada. - Bull. Fish. Res. Bd Can. 199, 1-270.

Noble, E. R., 1973. Parasites and fishes in a deep-sea environment. - Adv. mar. Biol, 11, 121-195.

Ortmann, A., 1896. Grundzüge der marinen Tiergeographie. Fischer, Jena, 96 pp.

Osmanov, S. V., 1940. Materials on the parasite fauna of fish of the Black Sea. (Russ.) - Uchen. Zap. Semingr. gos. Inst. 30, 187-265.

Parukhin, A. M., 1975. On distribution in the world ocean of Nematoda found in fish from the southern seas. (Russ.) - Vêst. Zool. 1, 33-38.

Polyansky, Yu. I., 1961. Zoogeography of the parasites of USSR marine fishes. In: Parasitology of fishes. Ed. by V. A. Dogiel, G. K. Petrushevsky \& Yu. I. Polyansky. Oliver \& Boyd, Edinburgh, 230-245.

Polyansky, Yu. I., 1966. Parasites of the fish of the Barents Sea. - I.P.S.T., Jeruslem, $158 \mathrm{pp}$.

Prudhoe, S. \& Bray, R. A., 1973. Digenetic trematodes from fishes. - Rep. B.A.N.Z. Antarctic Res. Exp. 1929-1931 (Ser. B: Zool. and Bot.) 8 (P. 10), 195-225.

Reimer, L. W. 1981. Zur Darstellung der Verwandtschaftsverhältnisse der Fischgattung Merluccius auf Grund des Parasitenbefalls. - Angew. Parasit. 22, 25-32.

Rohde, K., 1977. Species diversity of monogenean gill parasites of fish on the Great Barrier Reef. Proc. int. Coral Reef Symp., Miami, 3, 585-591.

Rohde, K., 1978a. Latitudinal gradients in species diversity and their causes. I. A review of the hypotheses explaining the gradients. -- Biol. Zbl. 97, 393-403.

Rohde, $K_{*} 1978 \mathrm{~b}$. Latitudinal gradients in species diversity and their causes. II. Marine parasitological evidence for a time hypothesis. - Biol. Zbl. 97,405-418.

Rohde, K., 1978c. Latitudinal differences in host-specificity of marine Monogenea and Digenea. Mar. Biol. 47, 125-134.

Rohde, K., 1980a. Warum sind ökologische Nischen begrenzt? - Naturw. Rdsch. Stuttg. 33, 98-102.

Rohde, K, 1980b. Diversity gradients of marine Monogenea in the Atlantic and Pacific Oceans. Experientia 36, 1368-1369.

Rohde, K., 1980c. Host specificity indices of parasites and their application. - Experientia 36, $1369-1371$.

Rohde, K., 1982. Ecology of marine parasites. Univ. Queensland Press, St. Lucia, 245 pp.

Rohde, K., Roubal, F. \& Hewitt, G. C., 1980. Ectoparasitic Monogenea, Digenea and Copepoda from the gills of some marine fishes of New Caledonia and New Zealand. - N.Z.Jl. mar. Freshwat. Res. 14, 1-13.

Roubal, F. R., 1981. The taxonomy and site specificity of the metazoan ectoparasites on the black bream, Acanthopagrus australis (Gunther), in northern New South Wales. - Aust. J. Zool. (Suppl.) 84, 1-100.

Roubal, F. R., Armitage, J. \& Rohde, K., 1983. Taxonomy of metazoan ectoparasites of snapper, Chrysophrys auratus (family Sparidae), from southern Australia, eastern Australia and New Zealand. - Aust. J. Zool. (Suppl.) 94, 1-71.

Schmarda, L. K., 1853. Die geographische Verbreitung der Thiere. Gerolt, Vienna. 
Shulman, S. S. \& Shulman-Albova, R. E., 1953. Parasites of fish of the White Sea. (Russ.) Isd. Akad. Nauk SSSR, Moscow, 199 pp.

Sogandares-Bernal, $F$, 1959. Digenetic trematodes of marine fishes from the Gulf of Panama and Bimini, British West Indies. - Tulane Stud. Zool. 7, 69-117.

Strelkov, Yu. A., 1960. Endoparasitic worms of marine fish of eastern Kamchatka. (Russ.) - Trudy zool. Inst, Leningr, 28, 147-196.

Szidat, L., 1961. Versuch einer Zoogeographie des Süd-Atlantik mit Hilfe von Leitparasiten der Meeresfische. - Parasit. SchrReihe 13, 1-98.

Yamaguti, S, 1970. Digenetic trematodes of Hawaiian fishes. Keigaku Publ., Tokyo, 436 pp.

Zhukov, E. V., 1960a. Endoparasitic worms of fish of the Sea of Japan and the South-Kuril shallow water. (Russ.) - Trudy zool. Inst., Leningr. 28, 3-146.

Zhukov, E. V, $1960 \mathrm{~b}$. On the fauna of parasites of fishes of the Chukotsk Peninsula and the adjoining seas. I. Monogenetic trematodes of marine and freshwater fishes. (Russ.) - Parazit. Sb. $19,308-332$.

Zhukov, E. V., 1976. Specific features of the trematode fauna of coastal fish in Cuba (Culf of Mexico). (Russ.) - Probl. Zool. 1976, 37-39. 